\title{
Research on the design of smart mountaineering gear based on solar power technology
}

\author{
Xiying Zhang ${ }^{1}$, Lei Shen ${ }^{1}$, Xiangfang Ren $^{1}$, Han Chen ${ }^{1}$, Ying Tang ${ }^{1.2}$ \\ ${ }^{1}$ Department of Design, Jiangnan University, Lihu Avenue, Wuxi, China \\ ${ }^{2}$ Department of Design, Politecnico di Milano, Milan, Italy
}

Corresponding Author: Lei Shen, s1999@sina.com

\begin{abstract}
Wearable devices were eagerly anticipated in science and technology circles and have led to large changes in the field of clothing. In addition to medical, military, industrial and other special fields, wearable devices are used in sports, fitness, entertainment and other tasks. The outdoor fitness field should promote new technology products; therefore, a new type of solar-charging mountaineering wear was designed using flexible solar cells sewn into a detachable double cap that is easy to use and has a high conversion efficiency. This paper introduces the overall system design, circuit design, and process design of the mountaineering gear and describes the experimental effects and prospects in detail.
\end{abstract}

\author{
ARTICLE HISTORY \\ Received: 26.06.2019 \\ Accepted: 12.06.2020

\section{KEYWORDS} \\ Renewable energy, solar cells, \\ wearable device, smart \\ clothing
}

\section{INTRODUCTION}

Wearable devices are the most remarkable development in the world of technology in the modern era. Devices were used in sneakers by Puma and Adidas when the companies experimented with wearable technology in the mid1980s[1]. With the development of complex new technology, the miniaturization and simplification of scientific and technological products, and the impetus of high-tech giants such as Google and Apple, wearable devices are now known to everyone and are increasingly being pursued. It is not a whim for these high-tech companies to make wearable devices the object of intense research and promotion, and some research institutes predict that by 2021 , the market size for smart wearable devices will reach $\$ 46.2$ billion, with a compound growth rate of $22 \%$ in the next four years[2]. This shows that the wearable market has a huge margin of profitability. In addition, high-tech products have a subtle impact on people's lives, changing their way of life. Smart phones have become popular electronic devices that have become inseparable from users in just a few years, and wearable devices will be the next tech fad, especially in the field of smart wearable clothing. Many famous brands have been developing smart wearable clothing. For instance, Ralph Lauren, a well-known fashion brand, launched Polo Tech, a smart compact sports T-shirt[3], becoming another new player in the wearable field. Adidas also introduced an intelligent basketball vest[4], and the Hexoskin brand has been leading the world in the field of motion sensing clothing and introduced a variety of men's and women's models of motion-sensing clothing[5] that can transmit realtime motion data to Bluetooth data points, including heart rate, number of steps, calorie consumption, respiration rate and other indexes, in a very advanced manner.

At present, smart wearable clothing involves medical, military, industrial and other special fields[6] and has immensely influenced people's daily life such as in sports, fitness, entertainment and other fields, especially in exercise fitness as heart rate bands, sensor clothing, and colourchanging clothes. Moreover, it increased the popularity of

To cite this article: Zhang X, Shen L, Ren X, Chen H, Tang Y. 2020. Research on the design of smart mountaineering gear based on solar power technology. Tekstil ve Konfeksiyon, 30(4), 231-238. 
and created an upsurge in sports enthusiasts. However, the outdoor fitness field also needs the impetus of new technology products. Mountaineering is one of the most popular outdoor sports. However, according to the 'relevant data analysis in the China mountaineering and outdoor sports accident analysis report' released by the Chinese mountaineering association, wayfinding accidents account for $45 \%$, and are one of the main types of outdoor mountain sports accident[7]. The three commonly used rescue methods are all based on positioning assistance, which needs unblocked positioning tools, like smartphones, navigation devices or GPS-enabled mountain watches. However, it is difficult to ensure that the electronic devices are always on during long climbing activities, and the power bank is not able to provide a continuous supply of energy.

A supply of energy is required in every field of electronic technology in the modern era. In this energy-scarce society, the development and utilization of renewable resources are predominantly important, and solar power generation is an emerging renewable resource. Approximately 40 minutes of solar energy on the earth are sufficient for the global human consumption in one year, it has no environmental pollution, is "green" and clean, inexhaustible, has no regional restrictions, and has broad application prospects. In recent years, researchers have made great progress in the study of solar textiles. In 2014, researchers at the MIT developed a new printing technology and successfully used it to make paper solar cells[8]. Traditional manufacturing methods require destructive conditions - printing substrates must be immersed in liquid or require high temperatures, whereas this new printing technology requires only steam and ambient temperatures below $120^{\circ} \mathrm{C}$. In this way, raw paper, clothing and plastic can all be used to make batteries that greatly reduce the cost of solar cells. In 2015, professors Trisha Andrew and Marianne Fairbanks of the University of Wisconsin-Madison and Noon Solar, co-founder of a solar-powered rechargeable handbag, developed solar textiles using polymers to coat different fabric types and structures, which increased the electrical conductivity of the fabric tenfold[9]. The same year, AdvancedMaterials described a solid-state photovoltaic textile in which the electro-linear photoanode wire (the negative electrode of the photovoltaic cell) and the counter electrode (the auxiliary electrode) are woven into a fabric layer. The two electrodes are placed on flexible, lightweight and inexpensive polymer fibres using a low-temperature wet treatment process. The new structure differentiates it from previous solar clothing made up of small solar cell elements. The new fabric receives energy from the natural solar radiation from the outside, charges the $2 \mathrm{mF}$ capacitor and reaches $3 \mathrm{~V}$ within $60 \mathrm{~s}$, generating enough electricity to power a digital calculator[10]. In 2018, researchers at the University of Tokyo developed a bendable ultra-thin organic solar cell with an energy conversion efficiency of 10.5 percent, setting a new record for the conversion efficiency of a bendable solar cell. The researchers, whose work is published in the journal Nature, combined the ultrathin organic solar cells with sensors to create an ultra-thin ECG monitor that can be attached to the skin[11]. In 2019, Nottingham Trent University researchers developed a technique using "miniature solar cells"; the technique allows the wearer to generate electricity in action and charge items such as watches and mobile phones, employing a battery the size of a flea that can be embedded in the yarn and woven into textiles like any other form of clothes with wash-and-wear resistance[12].

This paper is based on the use of solar energy resources and the latest industrialized solar textile technology to solve the needs and problems of mountaineering enthusiasts through the design and development of a new solar charging mountaineering clothing using the optical principle of converting light energy into electricity. A brief review of current research in the field of solar-charging clothing is presented below. In 2013, Pauline van Dongen, a fashion designer from Nijmegen University of Applied Science in Holland, and Christiaan Holland of Gelderland Valoriseert launched a solar rechargeable suit[13]. The rechargeable suit used rigid solar cells as its core device, and was paired with wool and leather as the main materials for the clothing. Although one hour could fill half the battery of an ordinary mobile phone, with 48 solar cells installed in the clothes, the overall weight of the clothing was heavy so it could only be worn in winter. American clothing brand Tommy Hilfiger is selling a unique winter coat that can recharge mobile phones[14] using flexible solar cells integrated in a removable part on the back; though the wearability is enhanced a lot, installing large charging cells on the back affects the activity and comfort of the wearer. Although those designs achieved energy conversion and realized the function of using clothing as a carrier to charge electronic equipment, they did not focus on the key points of wearer comfort for practical clothing and were not suitable for daily life activities. The solar charging mountaineering gear proposed in this paper is novel based on the above research. The flexible solar cell greatly reduces the weight of the item, and only 12 solar cells are installed to achieve the function of charging a mobile phone. In addition, the clothing combines the solar cells in a double hat structure that does not affect the wearer's activities and improves comfort. In the mountaineering clothing field, there is no mountaineering clothing that can charge electronic equipment, revealing an outdoor mountaineering power shortage problem or gap. Considering the above problems, this paper describes the design of a new type of solar charging mountaineering gear that uses renewable solar energy as the charging energy, perfectly integrating the charging device and clothing to achieve a union of functionality and aesthetics. The gear was designed on the premise that it should not add to the burden of climbing, it should be convenient for the wearer to use, and be exposed 
to the most light to maximize the conversion of solar energy into electricity.

\section{MATERIAL AND METHOD}

\subsection{Material}

Solar cells based on the principle of the semiconductor photovoltaic effect are an effective way to utilize solar energy. Thin-film solar cells are a new generation of solar cells, which can be divided into two categories of hard substrates and flexible substrates according to the type of substrates[15]. Considering the comfort level of clothing, this paper adopts the flexible ultra-thin solar cell as the carrier, and it will be the future direction of solar energy development that greatly surpasses the traditional silicon crystal laminates or the performance of film. The size and weight is $1 / 5$ th that of traditional solar cells, and the thickness is only $1 / 3$ rd that of the original cells, which will significantly promote the application of solar energy and enable solar energy technology in any shape or attached to any surface. As shown in Figure 1, the flexible solar cells are made by Wuxi Warmspace Tech C O., LTD, are bendable to nearly 180 degrees and have the advantage of being waterproof and sewn. The price is $\$ 3.50$ apiece. Data on the flexible ultra-thin solar cell are shown in Table 1, and the gauge is $0.5 \mathrm{~W} / 2 \mathrm{~V} / 250 \mathrm{~mA}$.

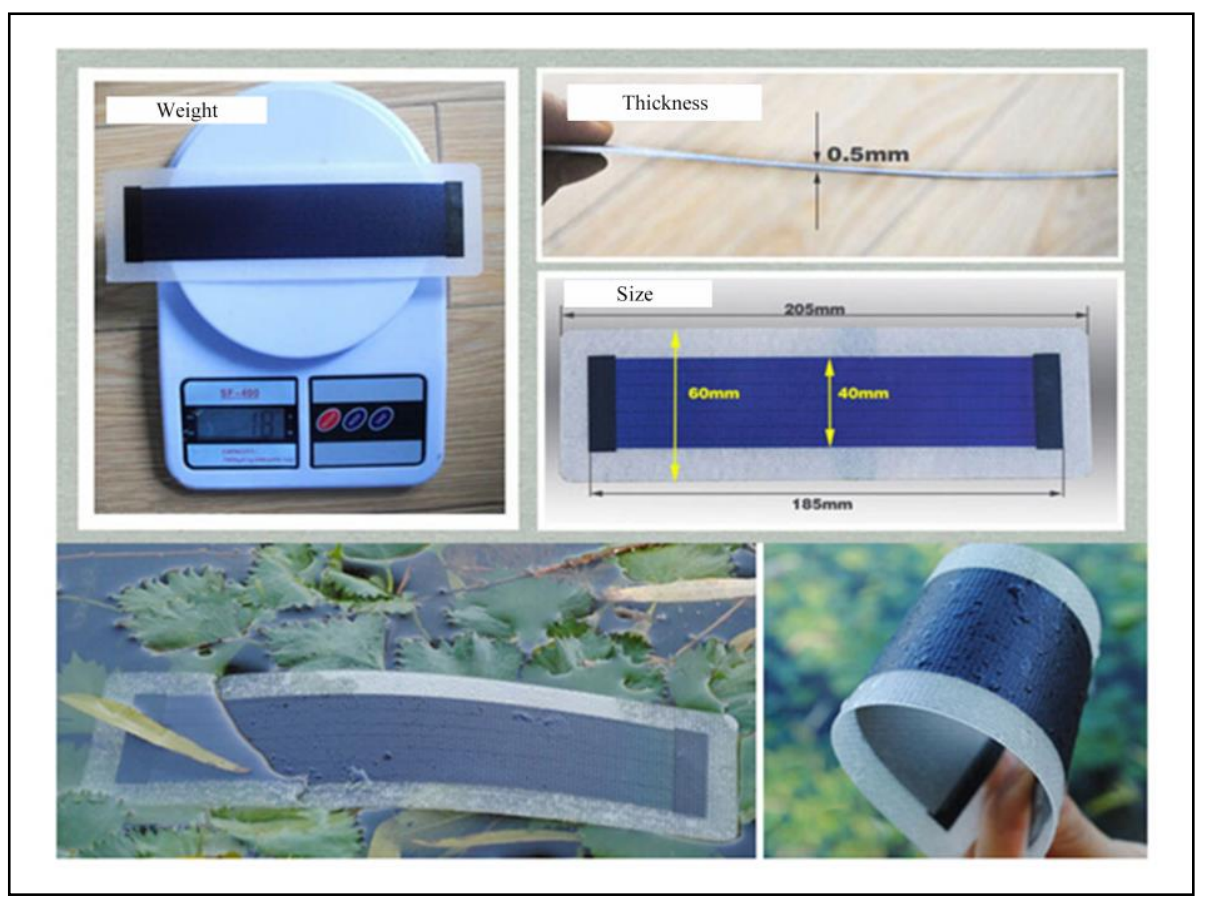

Figure 1. Flexible solar cell

Table 1. Data on monolithic flexible solar cells

(Note: The following electrical performance parameters were measured under standard test conditions: Light intensity $1000 \mathrm{~W} / \mathrm{L}$, spectrum AM1.5, cell temperature $25^{\circ} \mathrm{C}$ )

\begin{tabular}{|c|c|c|c|c|c|c|}
\hline Brand & Capacity & $\begin{array}{l}\text { Enviroment } \\
\text { temperature }\end{array}$ & Capability & Data & Specification & Others \\
\hline \multirow[t]{4}{*}{ WARMSPACE } & $0.5 \mathrm{~W}$ & $-40^{\circ} \mathrm{C} \sim 80^{\circ} \mathrm{C}$ & $\begin{array}{l}\text { Antiseptic } \\
\text { and } \\
\text { moisture- } \\
\text { proof }\end{array}$ & $\begin{array}{l}\text { Working voltage: } \\
1.5 \mathrm{~V}\end{array}$ & $\begin{array}{l}\text { Length: } \\
165 \mathrm{~mm} \\
\text { (Effective length), } \\
195 \mathrm{~mm} \\
\text { (Overall length) }\end{array}$ & $\begin{array}{l}\text { Packaging materials: } \\
\text { Durable, } \\
\text { High transmittance } \\
\text { ETFE film }\end{array}$ \\
\hline & & & & $\begin{array}{l}\text { Working current: } \\
250 \mathrm{~mA}\end{array}$ & $\begin{array}{l}\text { Width: } \\
38 \mathrm{~mm} \\
\text { (Effectivewidth), 58mm } \\
\text { (Overall width) }\end{array}$ & $\begin{array}{l}\text { Adhesive: } \\
\text { Weatherproof, } \\
\text { high transmittance fast } \\
\text { setting EVA film }\end{array}$ \\
\hline & & & & $\begin{array}{l}\text { Open-circuit } \\
\text { voltage: } 2.0 \mathrm{~V}\end{array}$ & $\begin{array}{l}\text { Thickness: } \\
0.5 \mathrm{~mm}\end{array}$ & $\begin{array}{l}\text { Battery type: } \\
\text { Three junctions of } \\
\text { flexible amorphous } \\
\text { silicon thin film solar } \\
\text { cells }\end{array}$ \\
\hline & & & & $\begin{array}{l}\text { Short-circuit } \\
\text { current: } 420 \mathrm{~mA}\end{array}$ & $\begin{array}{l}\text { Weight: } \\
18 \mathrm{~g} \pm 2 \mathrm{~g}\end{array}$ & \\
\hline
\end{tabular}


The clothing fabric was selected from the latest highquality DINTEX technical fabric. As shown in Figure 2, it uses the principle of nano-porous air permeability of top nanotechnology, integrates wind protection, air permeability and thermal technology, and has a double waterproof effect. The surface of the fabric is coated with a waterproof and breathable coating, and the inside is made of high-end $100 \%$ polyester fibre. DINTEX waterproof and breathable glue is used to adhere the inner waterproof and breathable film; the breathable coefficient reaches 5000, and rain and snow can be blocked from outside while the air inside can pass through the fabric. It has super-strong anti-rainstorm ability and has relaxed comfort.

\subsection{Method}

The circuit design mainly comprised study of the assembly structure of flexible ultra-thin solar cells and whether the attained energy/current can supply normal charging to electronic equipment. Considering the beauty of the clothing from an aesthetics point of view, the total area of the battery cell should be kept to a minimum. Using the flexible solar cell described above, theoretically, to meet the $3.7 \mathrm{~V} / 2000 \mathrm{mAh}$ capacity of an ordinary mobile phone lithium battery, 3 cells in series would take 8 hours to fill, 3 cells in series and 2 cells in parallel would take 4 hours to fill, 3 cells in series and 3 cells in parallel would take 2.7 hours to fill.

Considering the size of a normal hat and the process of combining a double hat (see details below), in this paper, 12 flexible ultra-thin solar cells were used to optimize the design; for the circuit design, three schemes were compared and tested.

Figure 3(a) shows the first scheme in which we adopted a LY9890 chip. The input end with 2 cells in series and 6 cells in parallel, the voltage after parallel is $4 \mathrm{~V}$ and the output is $5 \mathrm{~V}$ after the booster module. The LY9890 chip is a compact, efficient and low start voltage booster DC/DC converter chip that includes an error amplifier, slant wave signal generator, comparator, switch and drive component. When the load current varies in a large range, it can work stably and efficiently without any external compensation circuit. The input start voltage of the chip is below $1.6 \mathrm{~V}$. The higher switching frequency prominently reduces the size of the external components. In addition, the low static current of $5 \mathrm{uA}$ and high working efficiency ensure the battery has a long life. The output voltage is set by two external resistors. The output interface adopts a USB interface.

Figure 3(b) shows a second scheme using a TD1410 chip with an input of 6 cells in series and 2 cells in parallel; the voltage after parallel is $12 \mathrm{~V}$ and the output is $5 \mathrm{~V}$ after the depressurization module. TD1410 is a monolithic integrated buck switching power converter with internal power MOSFET. It has a wide voltage input range and can output 2 A current continuously. Using current mode, it has extremely high transient stability. Integrated heat turns off the function. In the turn-off mode, the current is less than $20 \mu \mathrm{A}$, and only a few peripheral devices are needed. The device includes a reference voltage source, oscillating circuit, error amplifier, and internal PMOS. The PWM control circuit can adjust the duty cycle from 0 to $100 \%$ linearly. It has a built-in overcurrent protection function and short-circuit protection function. Compensation modules are integrated to reduce the number of external components. TD1410 is the ideal power unit for portable devices.

Figure 3(c) shows the third scheme using a 3 cells in series and 4 cells in parallel connection mode, adding an antirecharge Schottky diode and parallel in each series to improve the efficiency of the solar charger as much as possible.

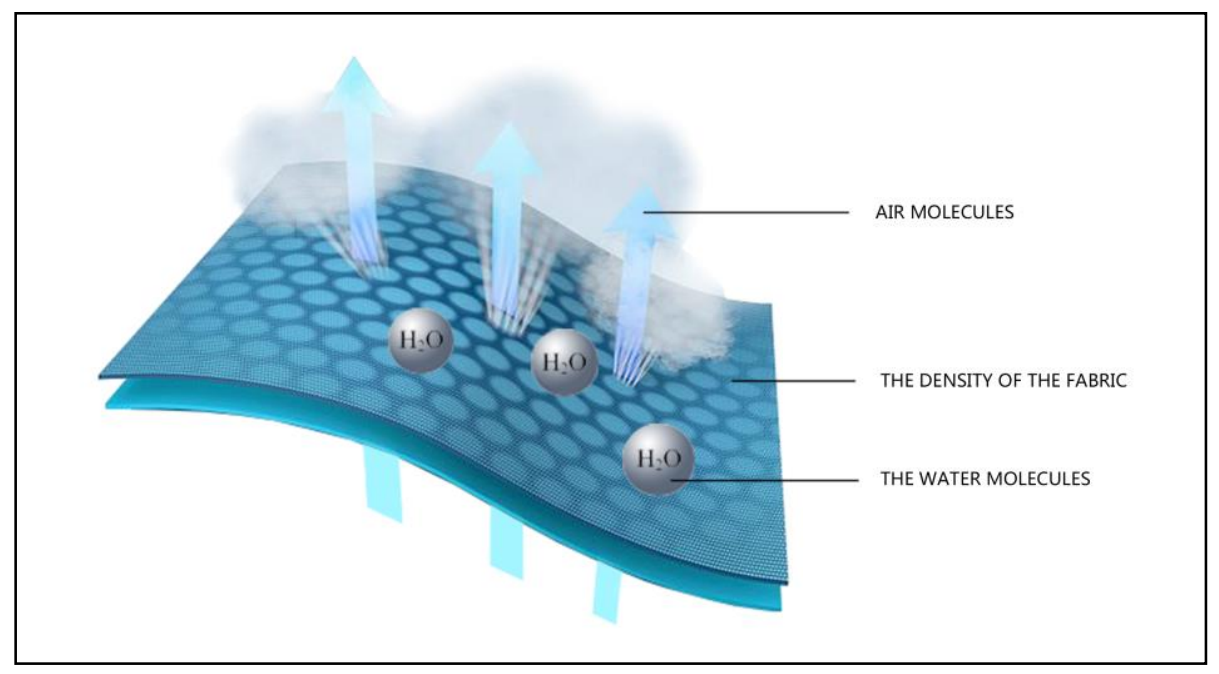

Figure 2. The principle of nano-porous air permeability 


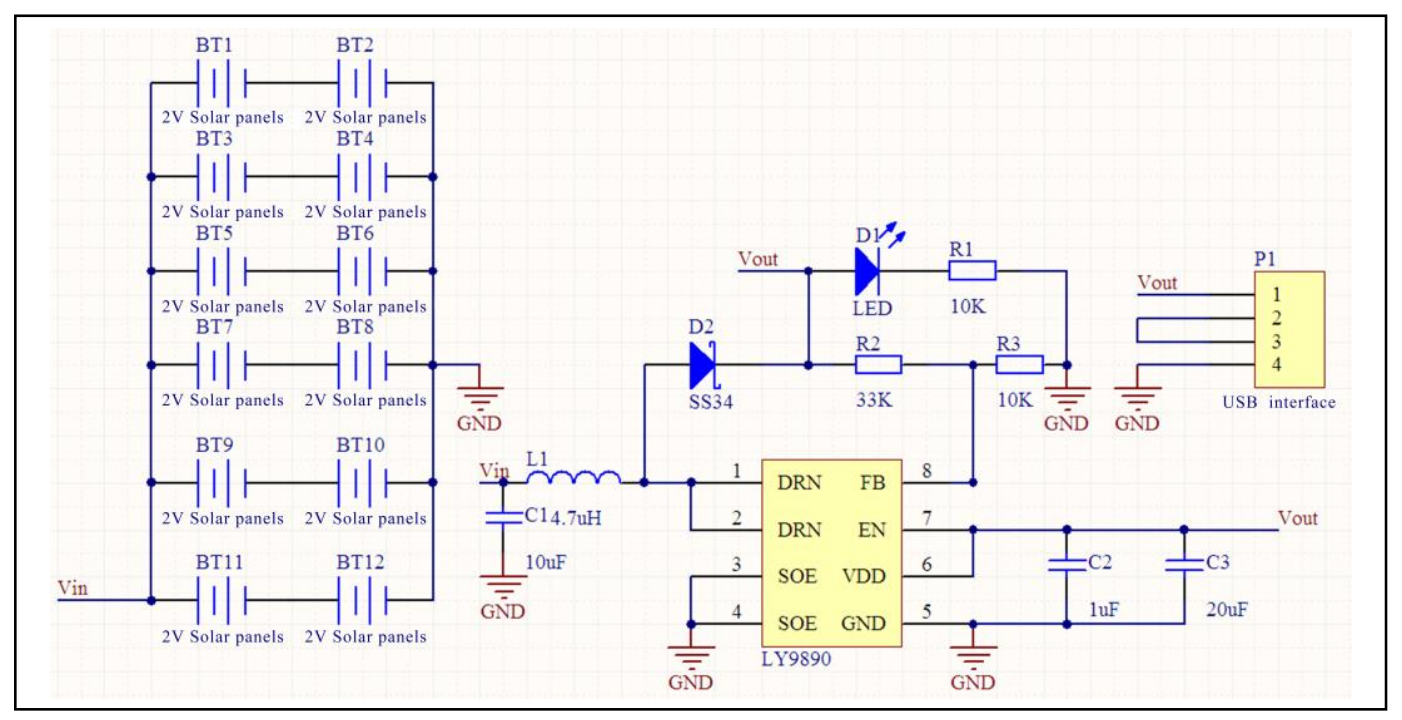

(a) $5 \mathrm{~V}$ boost circuit diagram

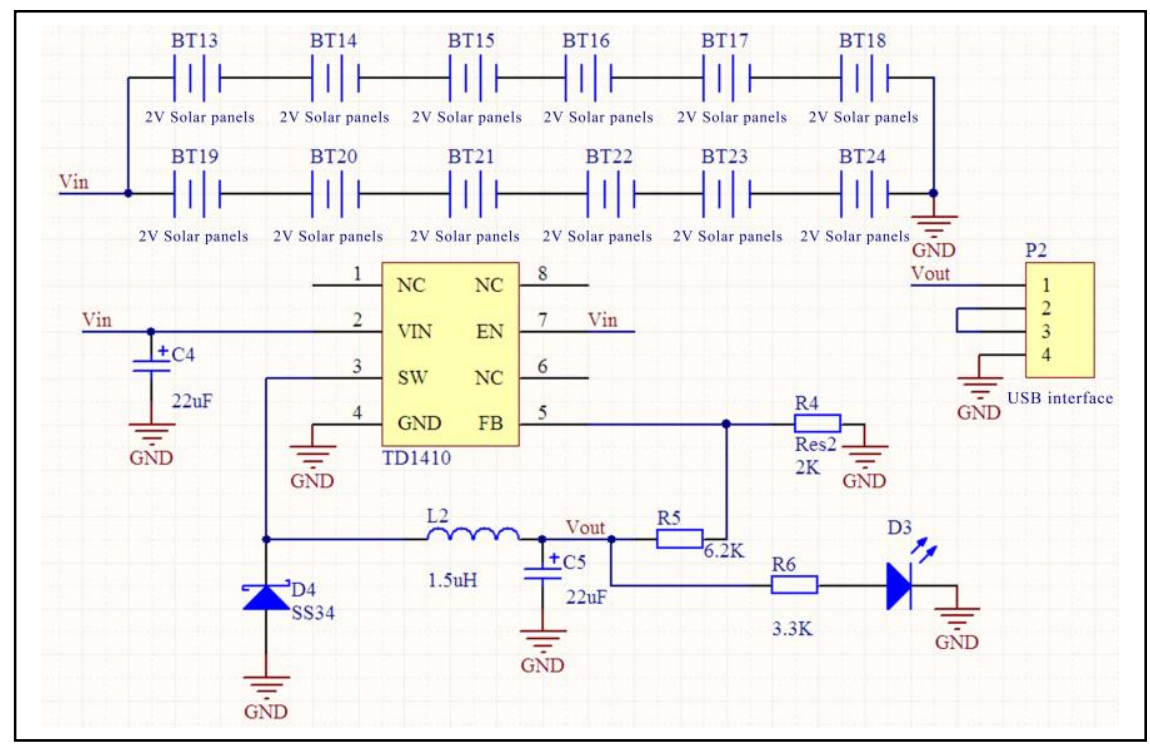

(b) $5 \mathrm{~V}$ buck circuit diagram

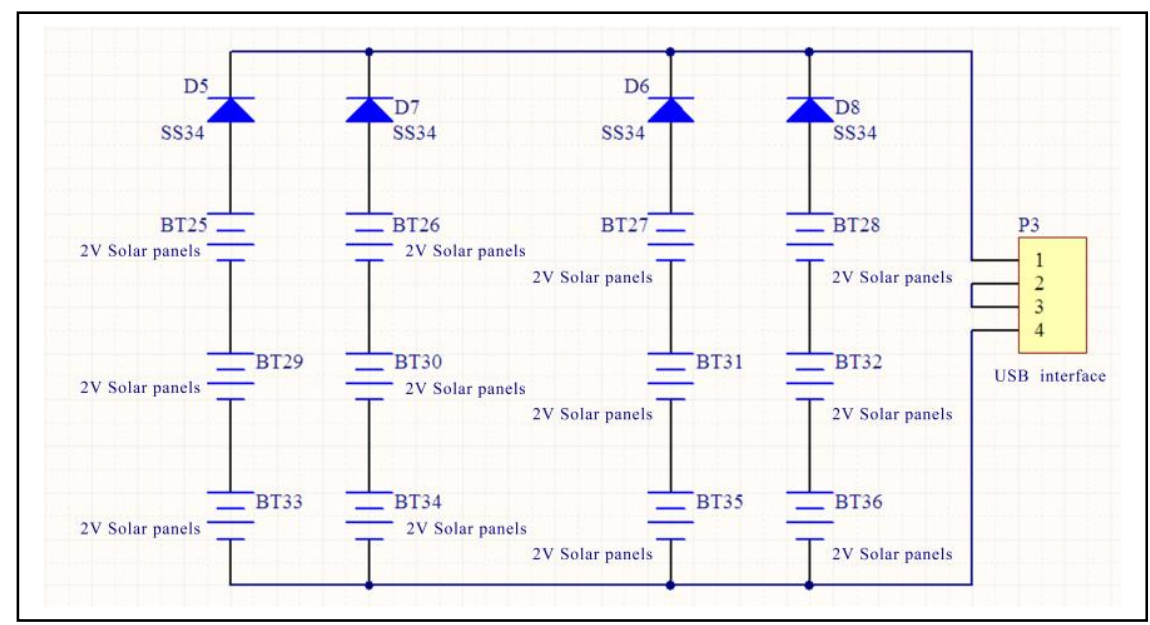

(c) Scenario 3 circuit diagram

Figure 3. Three circuit designs 
Although the output power of the flexible solar cell was stable, the light intensity was good and the conversion rate was only approximately $10 \%$, therefore, we must improve the efficiency of the circuit as much as possible to obtain the highest output current possible. Table 2 shows the results of above three schemes under normal sunlight.

The comprehensive comparison of the above three experimental schemes and did not consider the conversion cell rate; the conversion scheme efficiency of programme 1 was an average of $85 \%$, conversion efficiency of programme 2 was an average of $90 \%$, and programme 3 only had line and diode loss with an efficiency of up to $95 \%$. Therefore, the third scenario was used in the design case.

\section{RESULTS AND DISCUSSION}

As a design for the special group of climbers, we took the circumstances and habits of their activities into account. Climbers usually need to carry a hiking bag during hiking, so solar cells cannot be covered by backpacks and still receive the maximum amount of light. Considering the above special requirements, the author combined the flexible solar cell with the fabric, stitched it skilfully and made a removable mountaineering hat. The overall effect is shown in Figure 4. To achieve better power, and allow for more solar cells to receive light, it was designed as a double-decked hat. The whole hat is detachable; the outer layer of the hat is stitched together in six flexible ultra-thin solar cells and the outer hat is stitched into the interior. The outer hat is fitted with zippers in the middle that allow for it be expanded into a plane, as shown in Figure 5. This allows for more linear illumination and energy conversion for significant efficiency. In the cap fastener part, the design has a USB interface with an external hardware output module and an indicator light in the middle. When the solar cell is in the working state, the red indicator light will be on. The USB interface and design details are shown in Figure 6. Hikers can use this solar charging mountaineering gear at any time during the climb; all they need to do is put the inner hat on their head, open the outer cap zipper and put it on the their back or backpack, and connect an electronic device to charge via USB interface. Then, the hiker waits until the charging is complete.

Table 2. Results of three programs under normal sunlight irradiation

\begin{tabular}{llll}
\hline Programme & Total panel power(W) & Open circuit output voltage(V) & Output current(mA) \\
\hline 1 & 6 & 5.15 & 120 \\
2 & 6 & 5.20 & 260 \\
3 & 6 & 5.75 & 320 \\
\hline
\end{tabular}

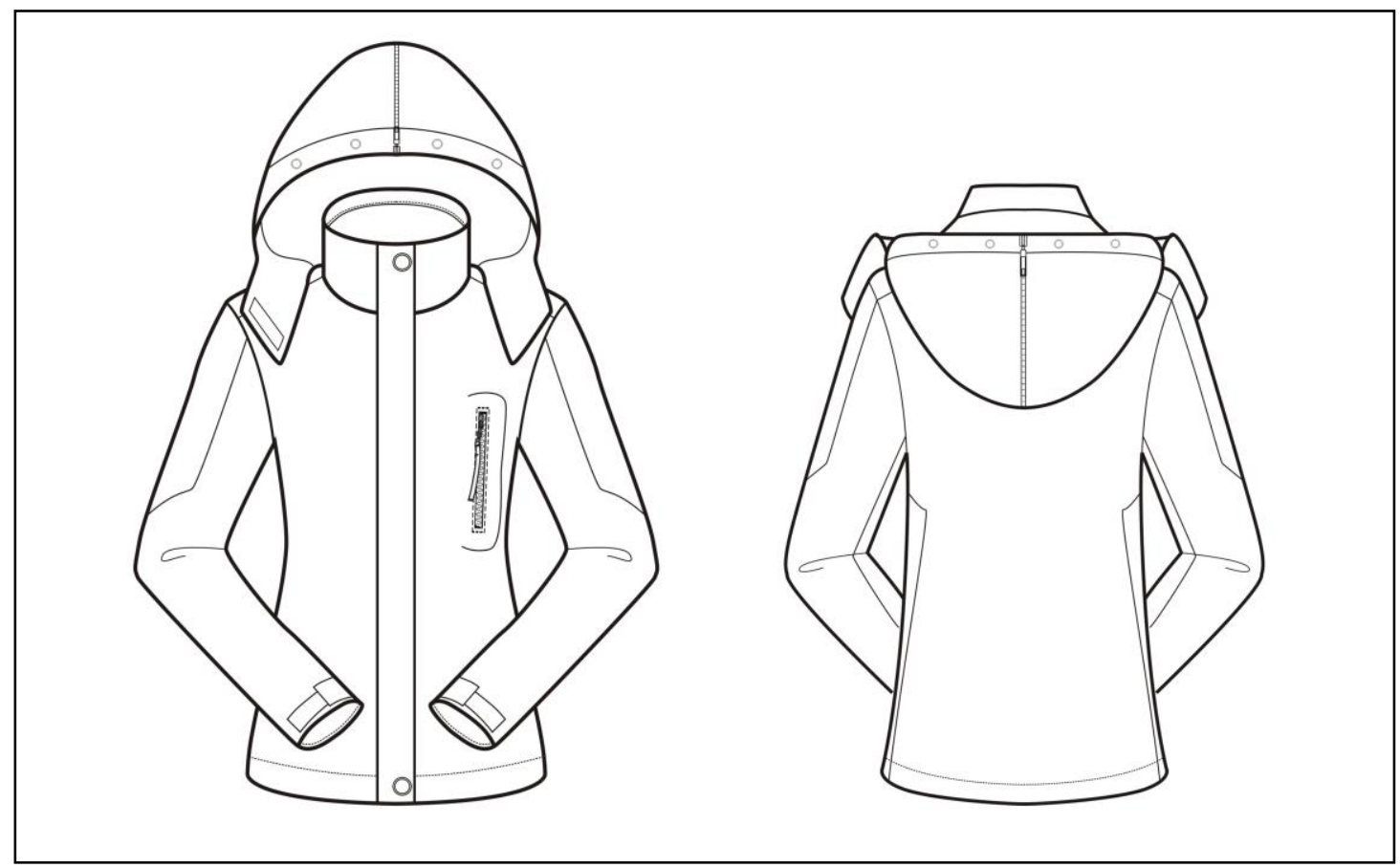

Figure 4. The front and back of the new solar-charging mountaineering gear 


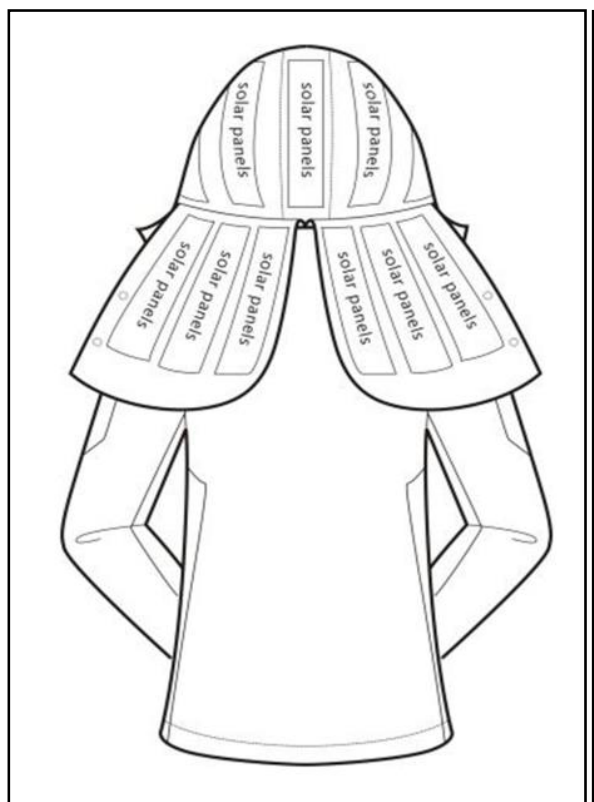

Figure 5. Expanding effect of the new solar-charging mountaineering gear
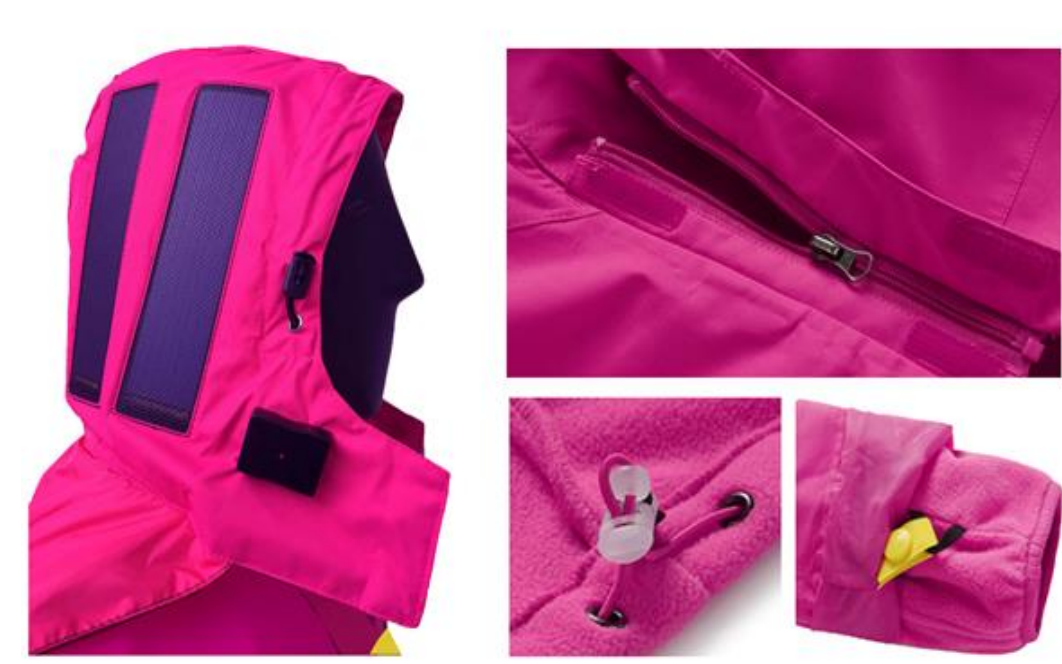

To ensure the normal use of the assembly structure of flexible solar cells combined with fabric, the author tested the clothing. The test method comprised connecting the flexible solar cell cell with a wire to a root number of two terminal units connected to a multimeter. The multimeter resistance reading was observed to determine whether the current and voltage met the charging requirements of general mobile phone lithium batteries, and conductive testing of all copper wires was performed to ensure the normal use of the charging system for solar-powered climbing gear.

Table 3 shows the experimental charging results for an ordinary mobile phone measured by sunlight exposure at different periods within 20 consecutive days in April. The table shows that, from 8 AM to $6 \mathrm{PM}$, the solar-charging mountaineering work efficiency with parabola distribution increased from $8 \mathrm{AM}$ to $12 \mathrm{PM}$, reached the peak at 12 with the best charging effect and maximum output current of 291 $\mathrm{mA} \pm 23 \mathrm{~mA}$. After 2 hours, the battery can be filled to $522 \mathrm{mAh} \pm 60 \mathrm{mAh}$. After $12 \mathrm{PM}$, the working efficiency began to decrease, as the illumination intensity gets weaker, so does the charging effect. The data for this experiment were the average of 20 days, and the statistical analysis of the data used Microsoft Excel 2013.
The climber's hiking activity time is generally on days of pleasant weather and there is little demand for cell phones in the mountaineering process, so this solar charging mountaineering gear can meet the requirements of climbers in the normal state of emergency charging.

\section{CONCLUSION}

Compared with previous solar clothing designs, this new solar mountaineering gear is lighter, softer, and more comfortable to wear. In addition to comfort, more solar cells are integrated so it has a higher conversion rate. Moreover, it is clean and environmentally friendly, makes full use of solar renewable resources, is easy to use, and can make up for the shortage in outdoor mountaineering power supply, promote the intelligent process of climbing clothes design. However, one inadequacy of the study lies in that the final test session only collected data for 20 days in April, which is not comprehensive enough for the use of the product. Subsequent laboratory tests should be more comprehensive and take measurements on days in each month of the year to generate average values for each month to provide a more instructive set of recommendations for future research.

Table 3. Average experimental sunlight exposure in different periods for 20 consecutive days in April

\begin{tabular}{lllllll}
\hline & $\mathbf{8 : 0 0}$ & $\mathbf{1 0 : 0 0}$ & $\mathbf{1 2 : 0 0}$ & $\mathbf{1 4 : 0 0}$ & $\mathbf{1 6 : 0 0}$ & $\mathbf{1 8 : 0 0}$ \\
\hline Illumination intensity $(\times 100$ Lux)* & $706 \pm 161$ & $829 \pm 177$ & $936 \pm 227$ & $871 \pm 198$ & $740 \pm 177$ & $547 \pm 140$ \\
Output current $(\mathrm{mA}) *$ & $239 \pm 25$ & $267 \pm 23$ & $291 \pm 23$ & $279 \pm 25$ & $256 \pm 23$ & $227 \pm 22$ \\
Open circuit output voltage $(\mathrm{V}) *$ & $5.3 \pm 0.1$ & $5.5 \pm 0.2$ & $5.7 \pm 0.2$ & $5.6 \pm 0.2$ & $5.4 \pm 0.2$ & $5.2 \pm 0.1$ \\
Charging time $(\mathrm{H})$ & 2 & 2 & 2 & 2 & 2 & 2 \\
Charge quantity $(\mathrm{mAh})$ & $290 \pm 28$ & $406 \pm 58$ & $522 \pm 60$ & $435 \pm 59$ & $348 \pm 56$ & $261 \pm 26$ \\
\hline
\end{tabular}


* Represents the result of the data within 20 days (average number \pm Standard deviation)

The 21 st century is the green age, also known as the ecological age, in which new forms of energy are being explored to make rational use of them with the common goal of eradicating this struggle. The emergence of new technology and materials as well as their processing, compounding and finishing will increase the growing trend of high-performance clothing and add to the trend of multifunctional progress for improvement of clothing efficiency. New materials of flexible solar cells have better wearability and durability than rigid solar cells, and can encourage designers' creativity in clothing design and promote the process of using solar energy resources in clothing. However, at present, there is still a contradiction between the combination of the electronic components and the clothing fabric, and the contradiction between energy consumption and performance makes the battery a bottleneck. For higher performance, the energy consumption is bound to increase and more solar cells can provide higher efficiency but the area for components and clothing is limited and design has become a difficult aspect. Safety, environmental protection and health are requirements of intelligent clothing in the new era. The harmonization and assimilation of electronic mechanisms and clothing design and development of smaller, thinner and more suitable methods for clothing electronic components will be a common goal.

\section{Acknowledgement}

This work was supported by the MOE (Ministry of Education in China) Project of Humanities and Social Sciences under Grant number 19YJC760096, and the Postgraduate Research \& Practice Innovation Program of Jiangsu Province under Grant number KYCX19_1849. The authors acknowledge the above financial support.

\section{REFERENCES}

1. Wen ZW. 2014. Clothing wearable technology. Textile machinery 14(5), 96-99.

2. Austen K. 2015. What could derail the wearables revolution? Nature 525(7567), 22-24.

3. Phau I, Sequeira M, Dix S. 2009. To buy or not to buy a "counterfeit" Ralph Lauren polo shirt: the role of lawfulness and legality toward purchasing counterfeits. Asia-Pacific Journal of Business Administration 1(1), 68-80.

4. Sun XF, Liu L. 2013. Wearable fashion design and innovation practice based on luminescent materials. Design Art Research 5 (2), 35-39.

5. Li L. 2014. A wearable device design-clothing computer. Electronics World 0 (11), 178-178.

6. Shen L, Hong W J, Tang Y. 2013. Design of new type of safety clothing based on the green era. Shanghai textile science \& technology 41(6), 48-50.

7. Chen GS. 2018. Research on development status and countermeasures of the mountain outdoor rescue (Master's thesis). Retrieved from Wuhan Institute of Physical Education.

8. LARGE. 2020, April 21st. Scientists develop technology to make paper solar cells. Retrieved from http://www.juda.cn/news/ 132376.html.
9. CIECC. 2015, September 9th. American researchers have developed new solar textile technology. Retrieved from http://gpj.mofcom. gov.cn/article/zuixindt/201509/20150901108291.shtml.

10. Huang YT. 2017. Self-charging textiles that do not require batteries. Dyeing \& Finishing 43(06), 55-56.

11. Science and Technology Daily, 2018, January 8th. Rubber made of very strong and tough materials could make washable solar battery. Retrieved from http://digitalpaper.stdaily.com/http_www.kjrb.com/ kjrb/html/2020-04/30/node_2.htm

12. Jinqiao textile net. 2019, January 17 th. Mobile phones can be charged by clothing made from tiny solar cells. Retrieved from https://www.sinotex.cn/newsHtml/190117/141256/.

13. Zhongguancun online, 2013, June 26th. Dutch designer pushes solar charging suit. Retrieved from http://news.zol.com.cn/382/ 3820472.html.

14. Guangzhou vocational training school of fashion art, 2014, Tommy Hilfiger entering the high-tech market, and pushing the solar charging jacket. December 16th. Retrieved from http://gzfatr.com/ ninfo.asp?id=2406.

15. Nie ZY. 2010. New flexible solar cells. Functional Materials Information 7(Z1), 127. 